\title{
How Do People Understand Urban Air Pollution? Exploring Citizens' Perception on Air Quality, Its Causes and Impacts in Colombian Cities
}

\author{
Omar Ramírez ${ }^{1,2 *}$, Ivan Mura3 ${ }^{3}$ Juan Felipe Franco ${ }^{4}$ \\ ${ }^{1}$ Environmental Engineering Program, Group of Applied Environmental Studies-GEAA, Universidad Nacional Abierta y a \\ Distancia-UNAD, Bogotá, Colombia \\ ${ }^{2}$ Associate Unit CSIC-University of Huelva “Atmospheric Pollution”, Centre of Research in Sustainable Chemistry-CIQSO, \\ Campus de El Carmen s/n, Huelva, Spain \\ ${ }^{3}$ COPA Research Group, Department of Industrial Engineering, Universidad de los Andes, Bogotá, Colombia \\ ${ }^{4}$ Group of Studies on Urban and Regional Sustainability (SUR), School of Engineering, Universidad de los Andes, \\ Bogotá, Colombia \\ Email: *omar.ramirez@unad.edu.co, ${ }^{\star}$ omarjrh@yahoo.com
}

How to cite this paper: Ramírez, O., Mura, I. and Franco, J.F. (2017) How Do People Understand Urban Air Pollution? Exploring Citizens' Perception on Air Quality, Its Causes and Impacts in Colombian Cities. Open Journal of Air Pollution, 6, 1-17. https://doi.org/10.4236/ojap.2017.61001

Received: February 4, 2017

Accepted: March 11, 2017

Published: March 14, 2017

Copyright $\odot 2017$ by authors and Scientific Research Publishing Inc. This work is licensed under the Creative Commons Attribution International License (CC BY 4.0).

http://creativecommons.org/licenses/by/4.0/

(c) (i) Open Access

\begin{abstract}
Similarly to other Latin American countries, urban air quality is a major concern in Colombia. The purpose of the present study was to explore citizens' perception on local air pollution, its causes and impacts. A questionnaire was individually applied to a sample of 994 participants. Relationships between demographic features and the perception on air quality were analyzed using a logistic regression, its odds ratio (OR), and a Chi-square test. Eighty percent of the respondents perceive their local air quality as either bad or fair, $65 \%$ recognize particulate matter as the main local air pollutant, and $90 \%$ recognize negative impacts on people's health as the main consequence of air pollution. In contrast to other studies where age and economic status are variables highly related with public perception on the level of atmospheric pollution, in this study only the size of the cities has a statistically significant relationship with the perception on local air quality regarding the level of pollution $(\mathrm{OR} \geq 1$, confidence intervals $>1$ and $p$-values $<0.05)$. While area sources such as mining and infrastructure construction are identified as the main sources of pollutant emissions in small towns (less than 50,000 inhabitants), in big cities, road traffic is identified as the main source contributor to atmospheric pollution. Opposite to data from official reports, and regardless of the size of the city, households are perceived as the place with greatest contribution to personal air pollution exposure. Results show that citizens are aware of the state of air quality and its health impact is a major concern. Such findings suggest people's opinions can be used as provisional indicators in cities without data, as well as to monitor the results of local air quality management. As a com-
\end{abstract}


plementary process, or at the same level of importance given to technicalbased policy, citizen participation can contribute to a collective construction of urban air pollution control strategies.

\section{Keywords}

Public Perception, Citizen Participation, Air Quality, Air Pollution, Colombia

\section{Introduction}

In Colombia, as in other Latin American countries, urban air pollution is a major concern [1] [2] [3] [4]. According to the monitoring made by national environmental authorities, particulate matter (PM) levels are well above national standards [5] [6]. Moreover, there is strong local evidence showing an association between low air quality conditions with higher rates of respiratory diseases [7] [8] [9] [10]. In many Colombian urban areas, public health authorities indicate that respiratory illness is the leading cause of morbidity and mortality among children under five years of age and represent one of the top causes of mortality across the entire population [11] [12] [13]. This condition has aroused the interest of the academia and scientific community to support the identification and characterization of the air pollution problem in different Colombian cities [14]. Such studies have supported the technical formulation of public policy strategies aiming at improving air quality.

Despite these efforts, much is yet to be done towards an improved understanding of the air pollution problem at a local level. While most of the research in Colombia has been focusing on the physical and chemical characterization of the problem, relatively no attention has been given to the socio-cultural aspects that underlie it. For instance, cities have neglected how different actors perceive air pollution problems and what is their level of concern, both individually and collectively.

Different reasons support the incorporation of social factors, in addition to economic and technical analysis, in the design and implementation of air quality policies. A comprehensive air quality management process requires information that reveals implicit socio-cultural aspects and the incorporation of a social value dimension [15]-[20]. Several case studies in policy making, demonstrate how public perception is crucial for environmental policies success. Delving into the social aspects can encourage public participation in air pollution control programs, especially if public is involved since early stages in decision-making processes [21]. Public consultation can be also useful to empower people in requesting the compliance to air quality standards [16]. And results of perception studies have an additional value, as they could be useful to enrich the analysis of scientific data or technical information.

In Colombia, there are few researches linking socio-cultural variables to air pollution. Daniels et al. [22] studied the perception on the impact of air pollu- 
tion on outdoors worker's health in the metropolitan area of Medellin. Other authors have analyzed the perception on environmental noise caused by vehicular traffic [23] [24] and the perception on air pollution problems coming from solid waste disposal [25]. The designing of Bogotá's Air Quality Management Plan included a participation process where several communities within the city were asked about their perception on air pollution, its causes and solutions [26]. Ariza et al. [27] also studied citizens' perception on the impact of air quality on health and quality of life in four localities in Bogota. These previous works have had a limited geographical scope and there is no registry of a previous nationwide air quality perception study. Within this context, this research aims to explore citizens' perception on local air pollution, its causes and consequences in different municipalities in Colombia.

\section{Methods}

\subsection{Participants and Sample}

Participants were third-year students from Environmental Engineering and Sanitation Technology undergraduate programs on distance-learning-methodology. Students under this learning methodology do not attend classes in a central campus, but follow the academic curriculum from different locations. This allows to have a sample with participants living in diverse cities in Colombia.

The objective population was 1775 people, which corresponds to the total enrolled students in the mentioned academic programs during the time-period of study (October 2014 to November 2015). The statistically representative size of the sample was calculated to be of 667 , considering an error of $3 \%$, a confidence level of $95 \%(\alpha=0.05)$ and a distribution of responses of $50 \%$. However, the final sample was made up of 994 participants, geographically distributed as shown in Figure 1.

\subsection{Questionnaire and Survey Method}

The questionnaire designed for the study included 15 questions, grouped in three sections: demographic characteristics, recognition of local environmental issues and understanding of the local air pollution condition (see Table 1). Questions were closed-answer except for some requesting additional description. The questionnaire was applied individually using an online platform.

As suggested by other authors [28] [29] [30] [31] [32], we used an online application for the survey because: a) participants were familiar with this practice; b) the possibility to have people from different geographical regions; c) the budget available for this research; d) its flexibility in data gathering and transcription; and e) lower bias-not having an interviewer. The questionnaire was pre-tested with a group of students of the target population in order to ensure face validity and comprehension of the survey.

\subsection{Statistical Analysis}

Questionnaire responses tabulation and graphical summaries were completed 


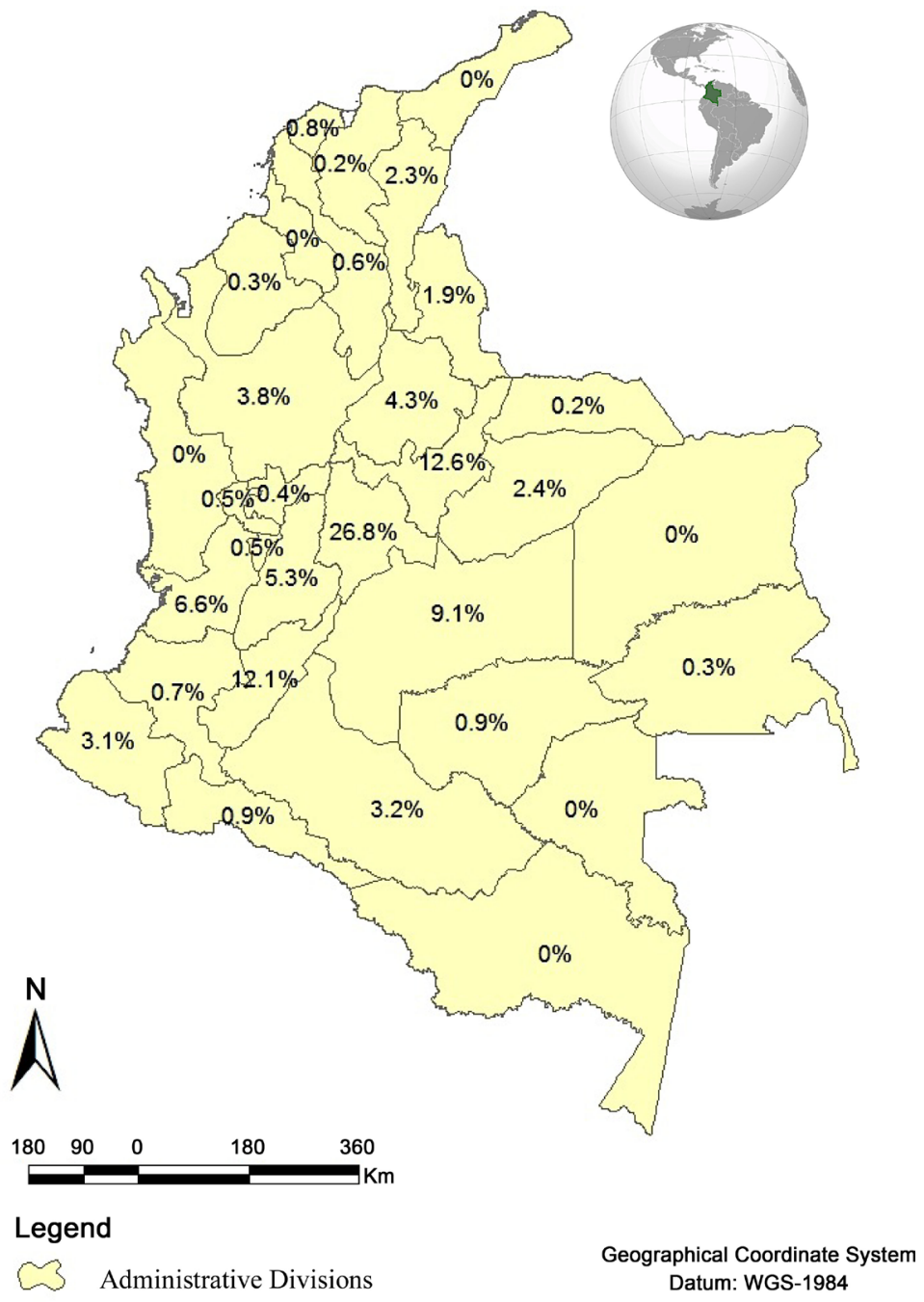

Figure 1. Map of Colombia with its administrative division (states) and the geographical distribution of the participants (\% of the total sample).

Table 1. Questionnaire structure.

\begin{tabular}{cc}
\hline Section & Question Subject \\
\hline Nemographic characteristics & Gender \\
Age & State \\
City & \\
Local environmental issues & Socioeconomic conditions \\
Identification of environmental problems \\
Ranking of environmental problems \\
Perception on \\
Air quality condition \\
Emission sources \\
Air pollutants \\
Magnitude of the impacts \\
Impacts description
\end{tabular}


with Microsoft Excel 2016, while statistical analyses were carried out using SPSS v.22 and R v.3.3.1 packages. To examine relationship between demographic characteristics and the perception on air quality a logistic regression was used. The odds ratio (OR) analysis consider that values of OR different than 1, with confidence intervals that do not include that value, express significant levels of association. The Chi-square test was used to assess the level of dependency between the demographic traits having the largest influence on air quality perception (according to the previously estimated OR) and other variables that could be potentially predictors of the local air pollution problem understanding (e.g., pollution sources). A $p$-value less than $5 \%$ was the criterion used to consider the test result as statistically significant.

\section{Results}

\subsection{Sample Characterization}

Table 2 shows the demographic characterization of the sample. Most respondents are women between 18 and 40 years of age. More than $95 \%$ of the participants live in households classified in socio economic strata 1,2 or 3 , with strata 2 being the one with highest percentage (44.9\%) (urban areas in Colombia and its dwellers are classified in six socio-economical strata, with stratum 1 being the lowest and stratum 6 the highest). As shown in Figure 1, we have a sample from different administrative regions in Colombia with the number of participants at each department representing a percentage of the total that varies from 0.2 to 26.8. Participants were categorized in five classes according to the size of their city or town (see Table 2).

\subsection{Relevance of Air Pollution as a Local Environmental Concern}

When asking participants about the three-main local environmental issues in their cities or towns of residence, water pollution was included in this list 77.8\% of the times, air pollution (together with offensive odors and noise) $74 \%$, inadequate solid waste management $65.3 \%$, and deforestation $35.7 \%$. Other environmental issues mentioned in a lesser extent were soil degradation (29.2\%), loss of plant and animal species (11.5\%), agrochemicals food contamination $(7.8 \%)$ and illegal wildlife trade (2.5\%). However, when deciding the leading environmental problem in the city, about $40 \%$ of the participants selected air pollution among the others (see Figure 2). This proportion was higher in large cities, with about $60 \%$ of the responses. In small towns, other environmental issues such as solid waste management, soil degradation, and water pollution are perceived as more relevant (see Figure 3).

\subsection{Perception on Local Air Quality}

Among the 994 responders, $80 \%$ perceive their city air quality as either bad or fair (see Figure 4). Table 3 lists the crude odds ratios (OR), confidence intervals (CI) and $p$-values resulting from the multivariate regression analysis. For these specific analysis, age and socioeconomic strata variables were grouped in three 
Table 2. Sample characteristics.

\begin{tabular}{|c|c|c|}
\hline Feature & $f$ & $\%$ \\
\hline \multicolumn{3}{|l|}{ Gender } \\
\hline Female & 600 & 60.4 \\
\hline Male & 394 & 39.6 \\
\hline \multicolumn{3}{|l|}{ Age } \\
\hline$<18$ & 21 & 2.1 \\
\hline $18-30$ & 721 & 72.5 \\
\hline $31-40$ & 206 & 20.7 \\
\hline$>40$ & 46 & 4.6 \\
\hline \multicolumn{3}{|l|}{ Socioeconomic status* } \\
\hline 1 & 224 & 22.5 \\
\hline 2 & 446 & 44.9 \\
\hline 3 & 279 & 28.1 \\
\hline 4 & 27 & 2.7 \\
\hline 5 & 14 & 1.4 \\
\hline $\mathrm{n} / \mathrm{a}$ & 4 & 0.4 \\
\hline \multicolumn{3}{|l|}{ City size (population) } \\
\hline$<50,000$ & 287 & 28.9 \\
\hline $50,000-100,000$ & 95 & 9.6 \\
\hline $100,000-250,000$ & 219 & 22.0 \\
\hline $250,000-500,000$ & 123 & 12.4 \\
\hline$>500,000$ & 270 & 27.2 \\
\hline
\end{tabular}

* In Colombia, urban areas and its dwellers are classified in six socio-economical strata, with stratum 1 being the lowest and stratum 6 the highest.

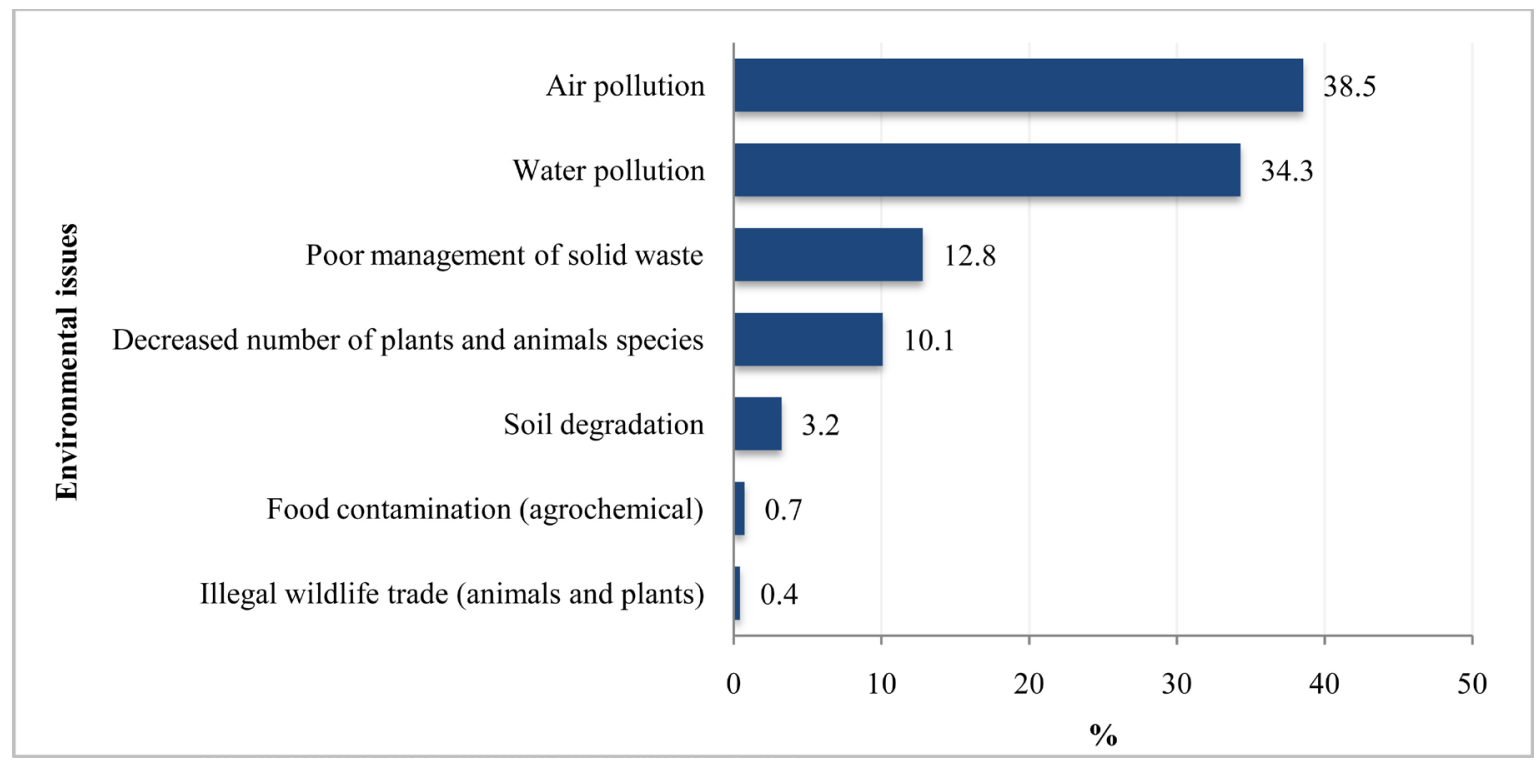

Figure 2. Leading local environmental problem in the city/town of residence (whole sample). 


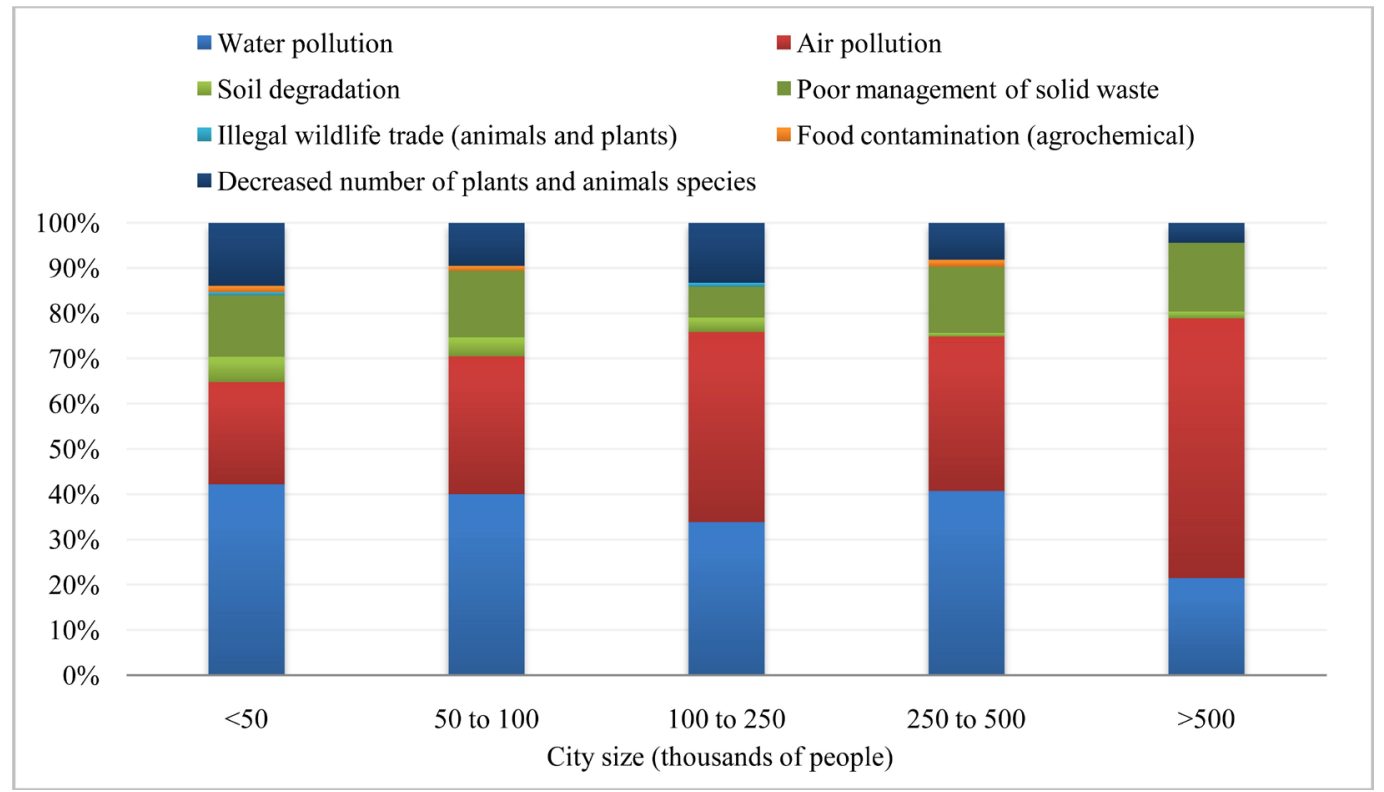

Figure 3. Leading local environmental problem in the city/town of residence classed by city size.

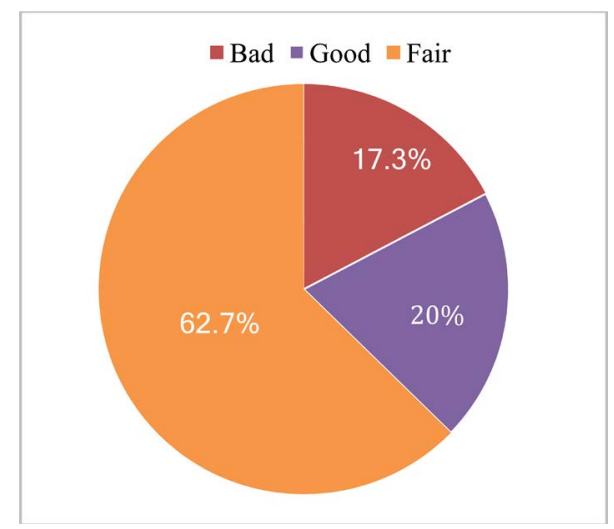

Figure 4. Perception on local air quality.

Table 3. Odds ratio for the demographic characteristics and perception on local air quality.

\begin{tabular}{|c|c|c|c|}
\hline & \multicolumn{3}{|c|}{ Crude Odds Ratio (OR) } \\
\hline & OR & $95 \% \mathrm{CI}$ & $p$-value \\
\hline \multicolumn{4}{|l|}{ Gender } \\
\hline Male to Female & 0.896 & $(0.693,1.158)$ & 0.404 \\
\hline \multicolumn{4}{|l|}{ Age } \\
\hline $18<$ Age $\leq 30$ to Age $<18$ & 0.797 & $(0.329,1.939)$ & 0.616 \\
\hline $30<$ Age $\leq 40$ to Age $<18$ & 0.656 & $(1.266,1.646)$ & 0.369 \\
\hline $40<$ Age to Age $<18$ & 0.916 & $(0.318,2.648)$ & 0.872 \\
\hline \multicolumn{4}{|l|}{ Socioeconomic strata } \\
\hline $3-6$ to $1-2$ & 0.677 & $(0.367,1.256)$ & 0.214 \\
\hline \multicolumn{4}{|l|}{ City population (in thousands) } \\
\hline $50<$ Size $\leq 100$ to Size $<50$ & 1.641 & $(1.032,2.624)$ & 0.037 \\
\hline $100<$ Size $\leq 250$ to Size $<50$ & 2.879 & $(1.982,4.202)$ & $<0.001$ \\
\hline $250<$ Size $\leq 500$ to Size $<50$ & 2.308 & $(1.494,3.585)$ & $<0.001$ \\
\hline $500<$ Size to Size $<50$ & 7.553 & $(5.222,11.001)$ & $<0.001$ \\
\hline
\end{tabular}


and two categories respectively. Participants with more than 55 years of age were included in the $>40$ class and respondents from socioeconomic strata 3,4, 5 and 6 where grouped to make this class equivalent in terms of size of the sample. With $\mathrm{OR} \geq 1$, confidence intervals $>1$ and $p$-values $<0.05$, we found an association between the size of the participant's city of residence and the perception of high local air pollution. This means a person living in a larger city is likely to have a negative perception on its air quality condition. Other variables such as gender, age and socioeconomic strata showed not statistical significance.

\subsection{Perception on Air Pollution Sources and Impacts}

Figures 5-9 show the participant's perception on other aspects that define the level of understanding of the air pollution problem at a local level. Those aspects included type of pollutant (gases or particles-PM), emission sources, health impacts and places associated with higher levels of air pollution exposure.

According to the Chi-square test level of significance, variables such as "type of contaminant" and "pollution sources" are dependent on the variable "size of the city" ( $p=0.02$ y $p<0.001$, respectively). Figure 5 shows that for all city classes, participants consider particulate matter (PM) as the main local air pollutant. In the cities with greater population this opinion becomes stronger. When asking participants about the primary source of air pollution in their location, 37\% of those living in smaller cities (less than 50,000 inhabitants) and considering PM as the main air pollutant, mentioned local area sources as the most important ones (mining, infrastructure construction and use of artisan furnaces in production processes located in the same area). On the other hand, $72 \%$ of those living in largest cities (more than 500,000 inhabitants) identified road traffic as the main source of PM (see Figure 6).

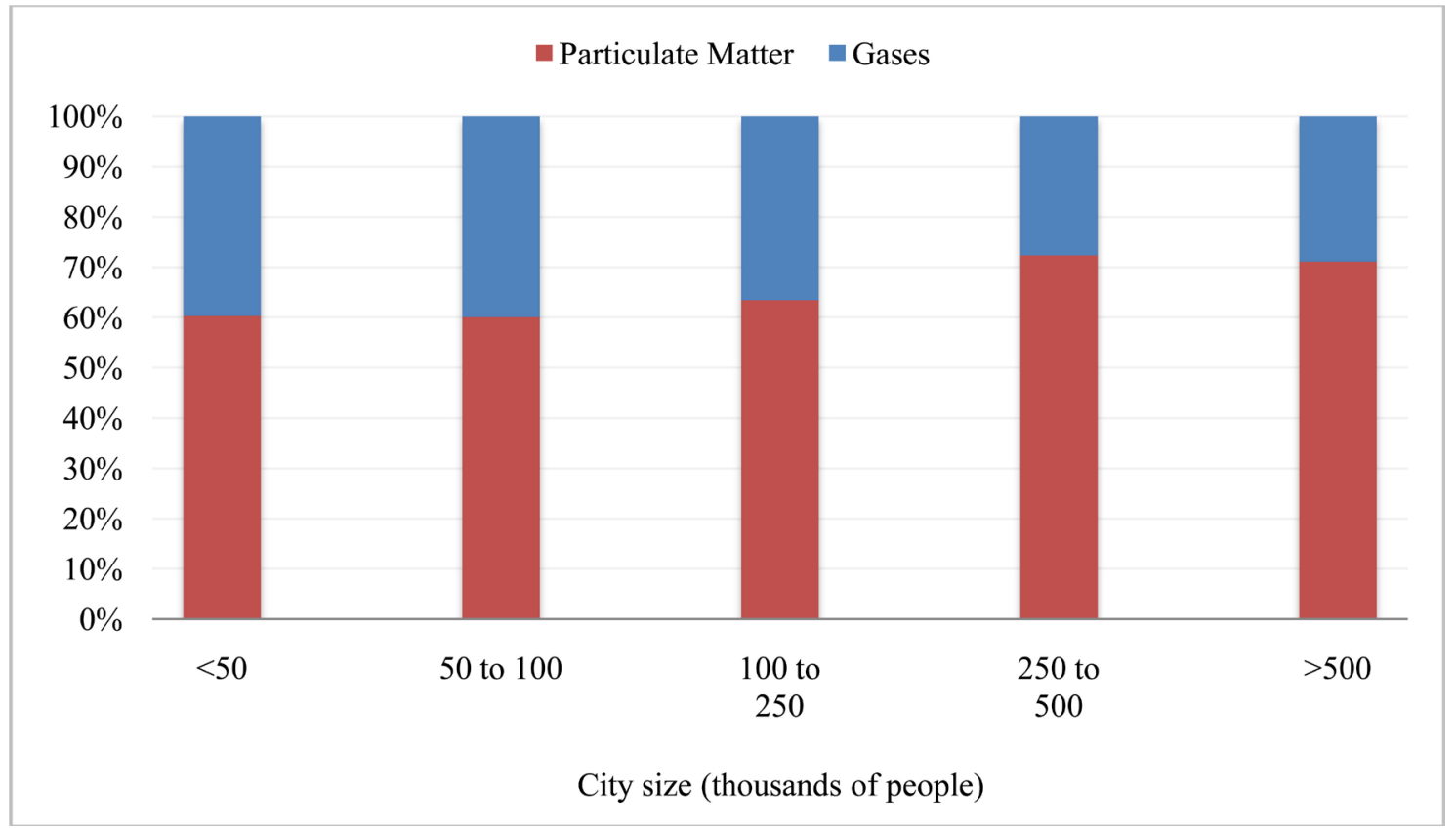

Figure 5. Perception on the main pollutant $\left(X^{2}=11.43, p=0.02\right)$. 


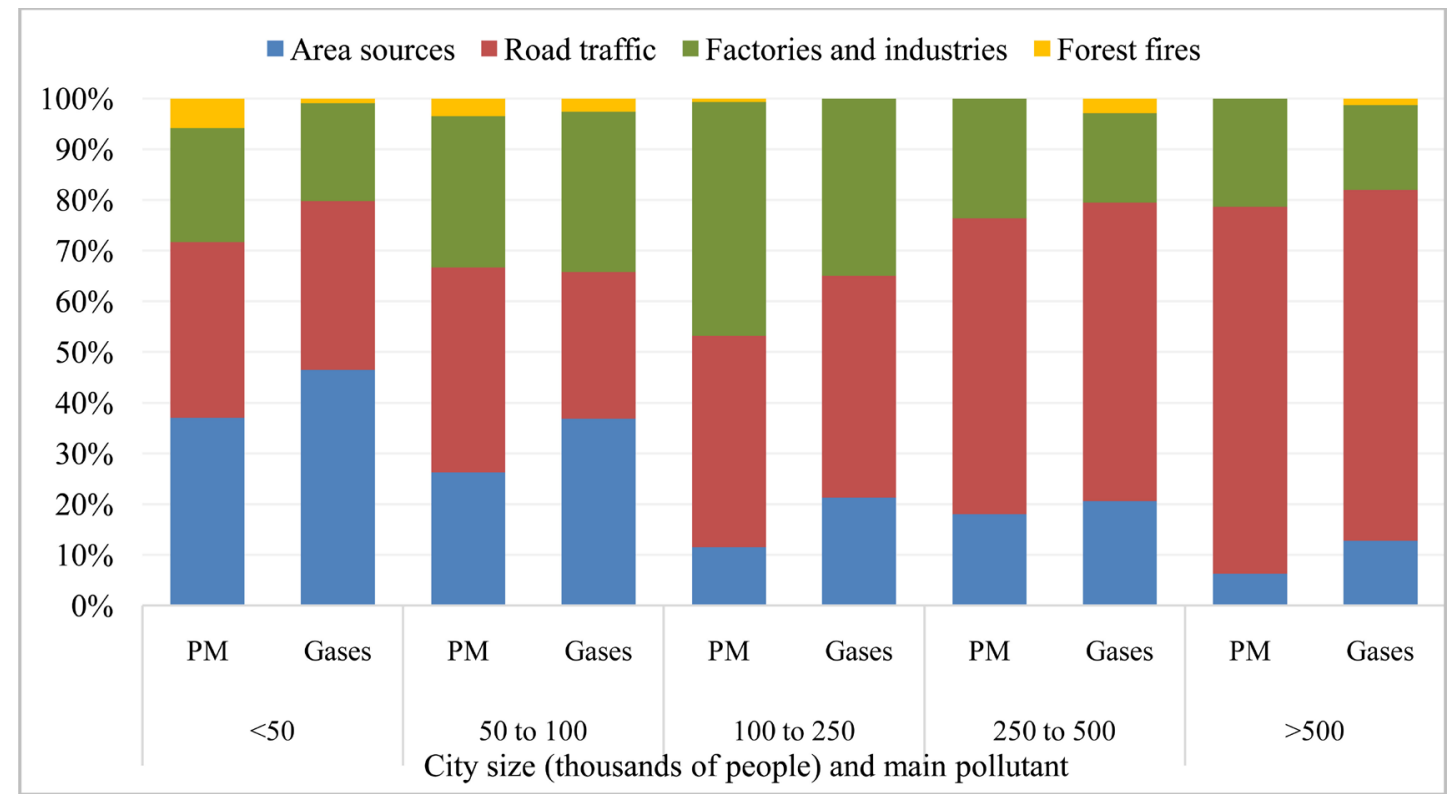

Figure 6. Perception on the main pollutant grouped by city size and primary source.

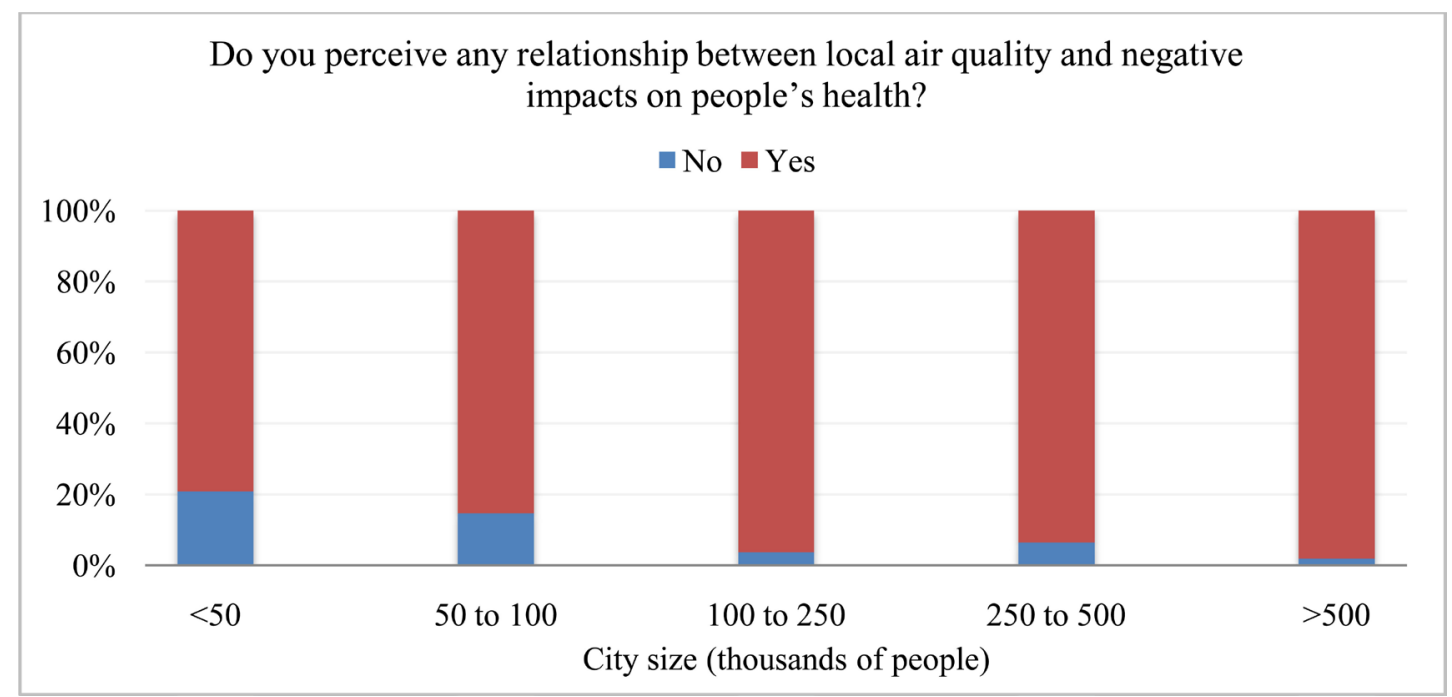

Figure 7. Perception on air pollution negative impact on people's health $\left(X^{2}=74.41, p<0.001\right)$.

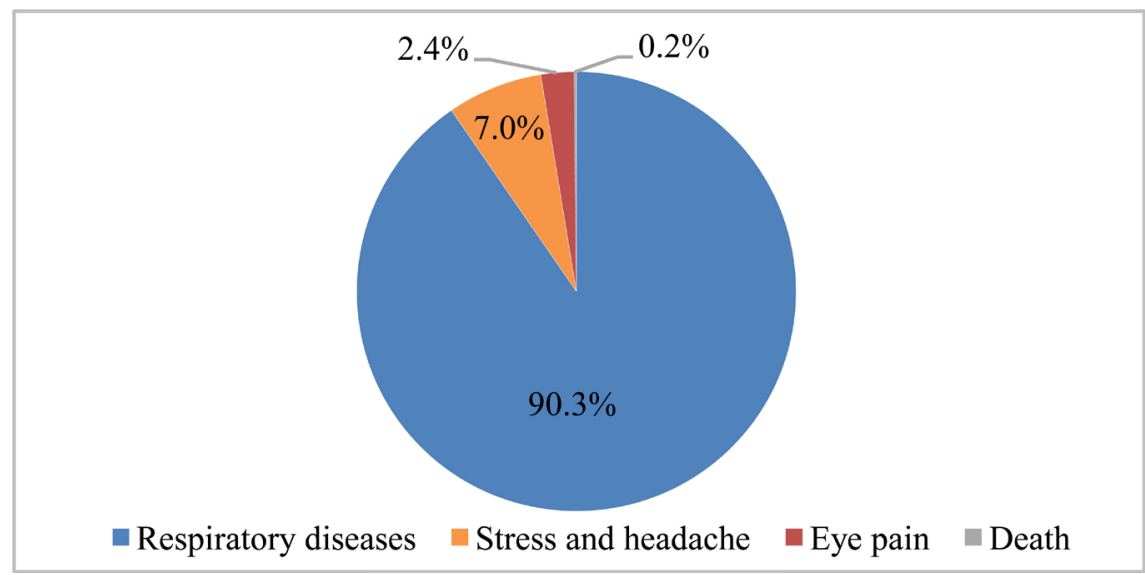

Figure 8. Perception on the primary air pollution impact on people's health. 


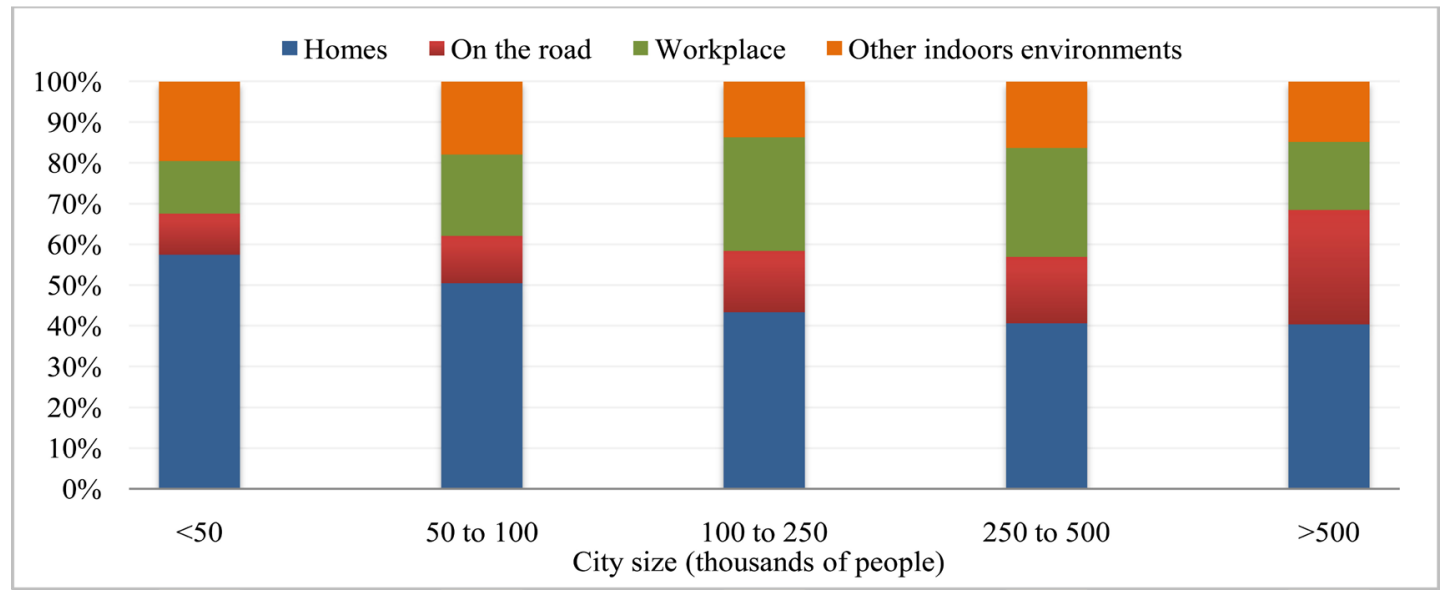

Figure 9. Perception on the place where public is more exposed to air pollution $\left(X^{2}=62.96, p<0.001\right)$.

More than $90 \%$ of the responders perceive air pollution as a negative factor affecting people's health (see Figure 7$)$. Statistical evidence $(p<0.001)$ demonstrates that the largest the city, the higher the participants' perception on the link between air quality and negative health impacts. Between those who perceive such relationship, more than $90 \%$ identified respiratory diseases as the main effect on health. The remaining percentage is distributed among other impacts such as eye pain, stress, headache and premature deaths (see Figure 8).

Figure 9 shows the participants perception regarding the places where they think they are more exposed to air pollution (inside their town of residence), classed by the size of the city $\left(X^{2}=62.96, p<0.001\right)$. About $60 \%$ of those living in towns with less than 50,000 inhabitants associate their homes with high levels of air pollution exposure. Participants from bigger cities perceive roadsides as an important place to be exposed to bad air quality. When asking about the scale of the impacts of air pollution, $62 \%$ of those recognizing the link between bad air quality and negative health effects, mentioned that impacts are predominantly manifested at a local level (i.e., in the city area), $20 \%$ at regional level (i.e., beyond the municipality) and $18 \%$ at a microscale level (i.e., neighborhood or village).

\section{Discussion}

These results contribute with evidence about citizens' perception on environmental issues in Latin American urban areas. As well as previous studies [33]-[38], our findings aim to improve the understanding of Colombia's urban air pollution condition and to highlight the potential of including citizen's perception as a way to support local action to address environmental problems. Taking advantage of the distance-learning-methodology of the undergraduate academic programs, we were able to have about 1000 respondents' sample, from different geographical regions in Colombia. As far as we are aware, this is the first study in the country and one of the few in Latin America with this number of participants, from different locations, examining opinions about air quality, its causes and impacts. 
There is a widespread concern about air quality within the participants. What local environmental authorities have identified regarding air pollution as a major problem in Colombian cities, is also perceived by the community. Contrary to preceding research [39] [40], no associations were found between perception on air quality and the three first factors in Table 2 describing respondents' personal characteristics (e.g., gender, age-group and socioeconomic strata).The fact that all participants were undergraduate students from environmental programs is of course giving a certain homogeneity to the sample, but it must however be notices that it cover people from a broad range of ages and different socioeconomic levels.

One factor we found associated with participant's perception was the size of the municipality. With OR different and higher than one, confidence intervals not crossing one and $p$-values less than 0.05 , the bigger the city of residence, the higher the probability to perceive air quality issues. This is consistent with previous research that highlight how town or city features have a significant influence on perceived levels of air pollution at the local level [41] [42] [43]. In particular, city size in terms of population appears to be a predictive factor, for the physical, social and cultural characteristics that it implies.

Despite most small and mid-sized cities do not have air quality monitoring networks and the fact that in Colombia air quality data is limited [5] [44] [45], $80 \%$ of respondents rated their local air quality condition as poor or fair. This means that citizens are aware of their own local environmental deterioration expressed as dust or some kind of smog and offensive odors [46] [47], but also that media (newspaper, television, online technical reports) might have an effect on participants' perception [38] [48] [49] [50]. These results provide an additional reason for local environmental and health authorities to implement measuring systems in those cities where air quality is not yet monitored.

Other authors have previously remark that air quality problems are especially critical in large cities with high population density [51] [52]. Consistently with that, about $60 \%$ of the responders from cities with more than 500,000 inhabitants perceived air pollution as the major environmental problem. When asking about the main local air pollutant, the majority (65\%) identified it with PM. This is also consistent with international and national reports that highlight the concern about the importance of PM levels in Latin American urban areas [4] [45] [53] [54] [55] [56] and its implications on human health [57], climate change [58], economy [59] and infrastructure [60]. Species such as greenhouse gases, associated to climate change, do not appear in the responses, which is interesting because it shows the level of knowledge of the respondents on this topic.

There is a statistical evidence for the relationship between perception on the emission sources and size of the city $\left(\mathrm{X}^{2}=166.98, p<0.001\right)$. In general, local area sources and forest fires have more relevance in small cities, while the importance of vehicular traffic as a source of air pollution, rises as the size of the city increases. Industries are more frequently mentioned as the main source of air pollution in mid-size cities (population between 100,000 and 250,000 inhabi- 
tants) (Figure 6).This is in accordance with results from previous studies, where characteristics such as the predominant economic activities in small and intermediate cities, and urban transport in larger cities, highly influence participants' perception on air quality [42] [43] [61].

Regarding the consequences of air pollution, although more than $90 \%$ of the total responders associated negative impacts on people's health, those living in major cities were more likely to recognize such harmful effect. Similarly, when asked about the place where people are more exposed to air pollution, participants of the largest cities mentioned roadsides in greater percentage in comparison to those in small and mid-size cities. However, in both small towns and large cities, respondents coincide on the household as the place where they are more exposed to air pollution. Such results reinforce the suggestion about the importance of considering concepts of healthy-home when designing housing projects.

Air pollution problems are complex and multidimensional, which demands to involve different perspectives for its analysis and management [17] [62] [63]. It is not about reducing the discussion to relativistic approaches, but a complete understanding of the local air quality scenario should include people's perception of the problem as a part of its indicators. In Colombian, and in more Latin American cities, it is time to start building local environmental polices together with people. We consider this is crucial since citizen participation in such public agenda can lead to generate strategies for a better environment. One first thing we suggest to do is to make environmental authorities more visible for the public, letting them know its presence, social objectives and institutional goals. Another key action should be to start monitoring air quality where it is not done today and make such data publicly available. An informed citizenry can make better decisions and will be empowered to follow the progress of the air pollution control actions [64] [65] [66].

\section{Conclusions}

Citizens' perception on local air pollution, its causes and consequences were explored in different municipalities in Colombia. Limitations notwithstanding, the authors want to highlight the questionnaire design and implementation process as a replicable instrument for broader studies in Colombia and Latin America. It is motivating the fact that participants were university students since they are call to later hold decision-making positions, in both public and private sectors.

The widespread perception of poor air quality should be a call for the authorities to initiate or intensify monitoring, and emissions control programs. Particulate matter was identified as a critical pollutant and people recognized adverse health effects as a main air pollution impact. Such findings suggest people's opinion can be a way to have indicators in cities without data, but also a way to track local air quality management. Moreover, this type of data may be used by environmental authorities to prioritize cities/regions to start acting. 


\section{Acknowledgements}

This study was funded by in part the Universidad Nacional Abierta y a Distancia (UNAD) in Colombian. The authors especially thank those students who voluntarily agreed to participate in the study by answering the questionnaire.

\section{References}

[1] OPS/Pan American Health Organization (2005) Assessment of Air Pollution Effects on Health in Latin America and the Caribbean. OPS/OMS, Washington DC. (In Spanish)

[2] WMO-World Meteorological Organization (2012) Impacts of Megacities on Air Pollution and Climate. GAW Report No. 205, World Meteorological Organization, Geneva.

[3] Romero-Lankao, P. and Gnatz, D. (2013) Exploring Urban Transformations in Latin America. Current Opinion in Environmental Sustainability, 5, 358-367. https://doi.org/10.1016/j.cosust.2013.07.008

[4] WHO-World Health Organization (2016) Preventing Disease through Healthy Environments: A Global Assessment of the Burden of Disease from Environmental Risks. WHO Document Production Services, Geneva.

[5] MAVDT-Ministry of Environment, Housing and Territorial Development (2010) Air Pollution Prevention and Control Policy. MAVDT, Bogotá. (In Spanish)

[6] IDEAM - Institute of Hydrology, Meteorology and Environmental Studies (2012) Report of the State of Air Quality in Colombia 2007-2010. IDEAM, Bogotá. (In Spanish)

[7] Ramírez, A., Sarmiento, O., Duperly, J., Wong, T., Rojas, N., Arango, C., Maldonado, A., Aristizábal, G., Pérez, L. and Lobelo, F. (2012) Should They Play Outside? Cardiorespiratory Fitness and Air Pollution among Schoolchildren in Bogotá. Revista de Salud Pública, 14, 570-583.

[8] Beleño, R., Quijano, A. and Meléndez, I. (2013) Mutagenic and Genotoxic Activity of Particulate Matter PM2.5 from Cucuta, Colombia. Revista MVZ Córdoba, 18, 3731-3737. (In Spanish)

[9] Estevez, J., Rojas, N. and Rodríguez, A. (2013) Occupational Exposure to Air Pollutants: Particulate Matter and Respiratory Symptoms Affecting Traffic-Police in Bogotá. Revista de Salud Pública, 15, 889-902.

[10] Ortiz, E. and Rojas, N. (2013) Estimating Air Quality Change-Associated Health Benefits by Reducing PM10 in Bogotá. Revista de Salud Pública, 15, 90-102. (In Spanish)

[11] Hernández, L., Aristizábal, G., Salgado, Y., Cantor, L., Medina, K. and Reyes, J. (2012) Association between Air Pollution and Morbidity from Acute Respiratory Illness in Children under Five in Three Locations in Bogotá. Pediatría, 45, 124-138. (In Spanish)

[12] Franco, J., Rojas, N., Sarmiento, O. and Behrentz, E. (2013) Urban Air Pollution in School-Related Microenvironments in Bogotá, Colombia. Revista Ingeniería e Investigación, 33, 42-48.

[13] Hernández, L., Aristizabal, G., Quiroz, L., Medina, K., Rodríguez, N., Sarmiento, R. and Osorio, S. (2013) Air Pollution and Respiratory Illness in Children Aged less than 5 Years-Old in Bogotá, 2007. Revista de Salud Pública, 15, 503-516. (In Spanish)

[14] Pachón, J. (2013) Research Trends Regarding Air Quality in Colombia, Based on 
the Results of the 4th Colombian Congress and International Conference on Air Quality and Public Health, 2013. Revista Épsilon, 21, 13-40. (In Spanish)

[15] Buttel, F. and Tylor, P. (1992) Environmental Sociology and Global Environmental Change: A Critical Assessment. Society \& Natural Resources, 5, 211-230. https://doi.org/10.1080/08941929209380788

[16] Bickerstaff, K. and Walker, G. (2001) Public Understandings of Air Pollution: The "Localization" of Environmental Risk. Global Environ Change, 11, 133-145. https://doi.org/10.1016/S0959-3780(00)00063-7

[17] Lezama, J. (2004) The Social and Political Construction of the Environment. El Colegio de México, México. (In Spanish)

[18] Hyland, J. and Donnelly, P. (2015) Air Pollution and Health-The Views of Policy Makers, Planners, Public and Private Sector on Barriers and Incentives for Change. Journal of Transport \& Health, 2, 120-126. https://doi.org/10.1016/j.jth.2015.03.006

[19] Ngo, N., Kokoyo, S. and Klopp, S. (2017) Why Participation Matters for Air Quality Studies: Risk Perceptions, Understandings of Air Pollution and Mobilization in a Poor Neighborhood in Nairobi, Kenya. Public Health, 142, 177-185.

https://doi.org/10.1016/j.puhe.2015.07.014

[20] Fischoff, B., Lichteinstein, S., Slovic, O., Derby, S. and Keeney, R. (1981) Acceptable Risk. Cambridge University Press, Cambridge.

[21] Pidgeon, N. (1998) Risk Assessment, Risk Values and the Social Science Programme: Why We Do Need Risk Perception Research. Reliable Engineering System Safety, 59, 5-15. https://doi.org/10.1016/S0951-8320(97)00114-2

[22] Daniels, F., Martínez, E., Quinchía, R., Morales, O., Romero, A., Marín, A. and Arbeláez, M. (2007) Air Pollution and the Population's Health Effects. Medellin and Its Metropolitan Area. Universidad de Antioquia, Medellín. (In Spanish)

[23] Narvaez, C., Ortiz, W. and Guerrero, R. (2011) Pasto Inhabitants' Perception on Environmental Noise Pollution Caused by Traffic Flow. Revista Unimar, 45, 5-14. (In Spanish)

[24] Ramírez, A. and Domínguez, E. (2014) Objective and Subjective Indicators of Traffic Noise Pollution in Chapinero District (Bogotá City, Colombia). Revista Gestión y Ambiente, 17, 45-54. (In Spanish)

[25] Valencia, J., Espinosa, A., Parra, A. and Peña, M. (2011) Perception of Risk Arising from Atmospheric Emissions from an Open Solid-Waste Disposal Site. Revista de Salud Pública, 13, 930-941. (In Spanish)

[26] SDA/Department of Environment (2010) Bogotá's Ten-Year Air Decontamination. SDA/Transmilenio SA/Universidad de Los Andes/Universidad de La Salle, Bogotá. (In Spanish)

[27] Ariza, L., Sánchez, M. and Franco, J. (2013) Citizen Perception about the Impact of Air Pollution on Their Health and Quality of Life: Pilot Study. Revista Épsilon, 21, 173-187. (In Spanish)

[28] Fox, J., Murray, C. and Warm, A. (2003) Conducting Research Using Web-Based Questionnaires: Practical, Methodological and Ethical Considerations. International Journal of Social Research Methodology, 6, 167-180. https://doi.org/10.1080/13645570210142883

[29] Pardos, S. (2006) Observation Techniques of Public Opinion in the Environmental Field. In: Coord, A.E., Eds., Public Opinion and the Environment, Editorial Graó, Barcelona, 70-118. (In Spanish)

[30] Kreuter, F., Presser, S. and Toureangeau, R. (2008) Social Desirability Bias in CATI, IVR and Web Surveys. Public Opinion Quarterly, 72, 847-865. 
https://doi.org/10.1093/poq/nfn063

[31] Vehovar, V., Manfreda, K. and Koren, G. (2008) Internet Surveys. In: Donsbach, W. and Traugott, M., Eds., The Sage Handbook of Public Opinion Research, Sage, Thousand Oaks.

[32] Chang, L. and Krosnick, J. (2010) Comparing Oral Interviewing with Self-Administered Computerized Questionnaires: An Experiment. Public Opinion Quarterly, 74, 154-167. https://doi.org/10.1093/poq/nfp090

[33] García, A. and Jaula, J. (2006) Environmental Perception of University of Pinar del Río Students. Innovación Educativa, 6, 39-45. (In Spanish)

[34] Sosa, M., Alcalá, J., Soto, R., Lebgue, T. and Quintana, C. (2008) Perception Environmental College Students through Environmental Variables. Revista Latinoamericana de Recursos Naturales, 4, 178-184. (In Spanish)

[35] Evrekli, E. and Balım, A. (2010) Effects of Mind Map and Concept Strips Use in Science and Technology Education on Students' Academic Achievement and Perception of Inquiry Learning Skills. Batı Anadolu Eğitim Bilimleri Journal, 1, 76-98.

[36] Ercan, F. (2011) Student Perceptions and Solutions about the Matters of Environment. Procedia-Social and Behavioral Sciences, 19, 450-452. https://doi.org/10.1016/j.sbspro.2011.05.153

[37] Karatekin, K. (2013) Perception of Environmental Problem in Elementary Students' Mind Maps. Procedia-Social and Behavioral Sciences, 93, 868-872. https://doi.org/10.1016/j.sbspro.2013.09.295

[38] Ramírez, O. (2015) Identification of Environmental Problems in Colombia from the Social Perception of University Students Located in Several Places of the Country. Revista Internacional de Contaminación Ambiental, 31, 293-310. (In Spanish)

[39] Kohlhuber, M., Mielck, A., Weiland, S. and Bolte, G. (2006) Social Inequality in Perceived Environmental Exposures in Relation to Housing Conditions in Germany. Environmental Research, 101, 246-255. https://doi.org/10.1016/j.envres.2005.09.008

[40] Atari, D., Luginaah, I. and Fung, K. (2009) The Relationship between Odour Annoyance Scores and Modelled Ambient Air Pollution in Sarnia, "Chemical Valley", Ontario. International Journal of Environmental Research and Public Health, 6, 2655-2675. https://doi.org/10.3390/ijerph6102655

[41] Wakefield, S., Elliot, S., Cole, D. and Eyles, J. (2001) Environmental Risk and (Re)Action: Air Quality, Health, and Civic Involvement in an Urban Industrial Neighbourhood. Health \& Place, 7, 163-177. https://doi.org/10.1016/S1353-8292(01)00006-5

[42] Howel, D., Moffatt, S., Prince, H., Bush, J. and Dunn, C. (2002) Urban Air Quality in North-East England: Exploring the Influences on Local Views and Perceptions. Risk Analysis, 22, 121-130. https://doi.org/10.1111/0272-4332.t01-1-00010

[43] Day, R. (2007) Place and the Experience of Air Quality. Health \& Place, 13, 249-260. https://doi.org/10.1016/j.healthplace.2006.01.002

[44] MADS-Ministry of Environment and Sustainable Development (2013) Urban Environmental Quality Index-ICAU. MADS, Bogotá. (In Spanish)

[45] MADS-Ministry of Environment and Sustainable Development (2015) National Urban Environmental Quality National Report: Urban Areas with Population above 500,000. MADS, Bogotá. (In Spanish)

[46] Elliott, S., Cole, D., Krueger, P., Voorberg, N. and Wakefield, S. (1999) The Power of Perception: Health Risk Attributed to Air Pollution in an Urban Industrial Neighbourhood. Risk Analysis, 19, 621-634. 
https://doi.org/10.1111/j.1539-6924.1999.tb00433.x

[47] Howel, D., Moffatt, S., Bush, J., Dunn, C. and Prince, P. (2003) Public Views on the Links between Air Pollution and Health in Northeast England. Environmental Research, 91, 163-171. https://doi.org/10.1016/S0013-9351(02)00037-3

[48] McDonald, J., Hession, M., Rickard, A., Nieuwenhuijsen, M. and Kendall, M. (2002) Air Quality Management in UK Local Authorities: Public Understanding and Participation. Journal of Environmental Planning and Management, 45, 571-590. https://doi.org/10.1080/09640560220143567

[49] Schwartz, J. (2006) Air Pollution: Why Is Public Perception So Different from Reality? Environmental Progress \& Sustainable Energy, 25, 291-297.

[50] Oltra, C. and Sala, R. (2014) A Review of the Social Research on Public Perception and Engagement Practices in Urban Air Pollution. CIEMAT/Departamento de Medio Ambiente, Madrid.

[51] Gurjar, B., Butlerb, T., Lawrenceb, M. and Lelieveld, J. (2008) Evaluation of Emissions and Air Quality in Megacities. Atmospheric Environment, 42, 1593-1606. https://doi.org/10.1016/j.atmosenv.2007.10.048

[52] Grobéty, B., Gieré, R., Dietze, V. and Stille, P. (2010) Airborne Particles in the Urban Environment. Elements, 6, 229-234. https://doi.org/10.2113/gselements.6.4.229

[53] Sanchez, E., Ahmed, K. and Awe, Y. (2007) Environmental Priorities and Poverty Reduction: A Country Environmental Analysis of Colombia Directions in Development: Environment and Sustainable Development. The World Bank, Washington DC.

[54] Green, J. and Sanchez, S. (2013) Air Quality in Latin America: An Overview. Clean Air Institute, Washington DC.

[55] Franco, J., Segura, J. and Mura, I. (2016) Air Pollution alongside Bike-Paths in Bogotá-Colombia. Frontiers in Environmental Science, 4, 77. https://doi.org/10.3389/fenvs.2016.00077

[56] Tyler, N., Acevedo, J., Bocarejo, J. and Velásquez, J. (2013) Theoretical Framework of Air Pollution in Colombia. University College London/Universidad de Los Andes, Bogotá. (In Spanish)

[57] Lu, F., Xu, D., Cheng, Y., Dong, Sh., Guo, Ch., Jiang, X. and Zheng, X. (2015) Systematic Review and Meta-Analysis of the Adverse Health Effects of Ambient PM2.5 and PM10 Pollution in the Chinese Population. Environmental Research, 136, 196204. https://doi.org/10.1016/j.envres.2014.06.029

[58] IPCC-Intergovernmental Panel on Climate Change (2014) Climate Change 2014: Synthesis Report. Contribution of Working Groups I, II and III to the Fifth Assessment Report of the Intergovernmental Panel on Climate Change. IPCC, Geneva.

[59] World Bank (2016) The Cost of Air Pollution: Strengthening the Economic Case for Action. The World Bank \& IHME, Washington DC.

[60] Liu, B., Wang, D., Guo, H., Ling, Z. and Cheung, K. (2015) Metallic Corrosion in the Polluted Urban Atmosphere of Hong Kong. Environmental Monitoring and Assessment, 187, 4112. https://doi.org/10.1007/s10661-014-4112-Z

[61] Simone, D., Eyles, J., Newbold, K., Kitchen, P. and Williams, A. (2012) Air Quality in Hamilton: Who Is Concerned? Perceptions from Three Neighbourhoods. Social Indicators Research, 108, 239-255. https://doi.org/10.1007/s11205-012-0064-2

[62] Funtowicz, S. and Ravetz, J. (1990) Uncertainty and Quality in Science for Policy. Kluwer Academic Publishers, Dordrecht.

[63] Cupples, J. (2009) Culture, Nature and Particulate Matter-Hybrid Reframings in Air Pollution Scholarship. Atmospheric Environment, 43, 207-217. 
https://doi.org/10.1016/j.atmosenv.2008.09.027

[64] Simioni, D. (2003) Air Pollution and Citizen Awareness. CEPAL, Santiago de Chile. (In Spanish)

[65] Catalan, M., Riojas. H., Jarillo, E. and Delgadillo, H. (2009) Perception of Health Risks Due to Air Pollution in Adolescents in Mexico City. Salud Públicaen de México, 51, 148-156. (In Spanish)

[66] Liao, X., Tu, H., Maddock, J., Fan, S., Lan, G., Wu, Y., Yuan, Z. and Lu, Y. (2015) Residents' Perception of Air Quality, Pollution Sources, and Air Pollution Control in Nanchang, China. Atmospheric Pollution Research, 6, 835-841.

https://doi.org/10.5094/APR.2015.092

Submit or recommend next manuscript to SCIRP and we will provide best service for you:

Accepting pre-submission inquiries through Email, Facebook, LinkedIn, Twitter, etc. A wide selection of journals (inclusive of 9 subjects, more than 200 journals)

Providing 24-hour high-quality service

User-friendly online submission system

Fair and swift peer-review system

Efficient typesetting and proofreading procedure

Display of the result of downloads and visits, as well as the number of cited articles Maximum dissemination of your research work

Submit your manuscript at: http://papersubmission.scirp.org/

Or contact ojap@scirp.org 